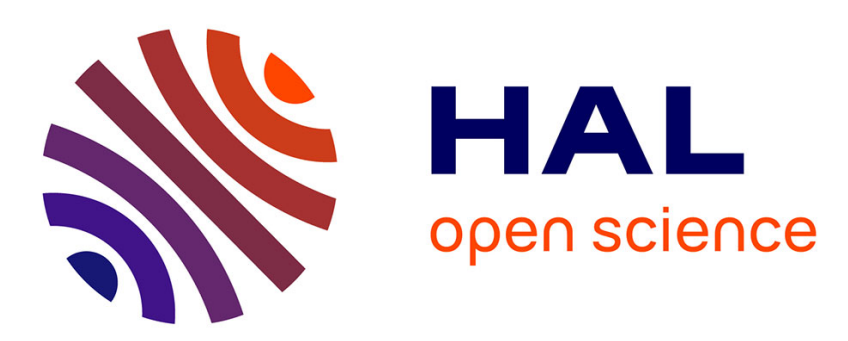

\title{
Coupled effects of aggregate size and alkali content on ASR expansion
}

Stéphane Multon, Martin Cyr, Alain Sellier, Ali-Nordine Leklou, Laurent Petit

\section{To cite this version:}

Stéphane Multon, Martin Cyr, Alain Sellier, Ali-Nordine Leklou, Laurent Petit. Coupled effects of aggregate size and alkali content on ASR expansion. Cement and Concrete Research, 2007, 38 (3), pp.350-359. 10.1016/j.cemconres.2007.09.013 . hal-01006003

\section{HAL Id: hal-01006003 https://hal.science/hal-01006003}

Submitted on 17 Oct 2017

HAL is a multi-disciplinary open access archive for the deposit and dissemination of scientific research documents, whether they are published or not. The documents may come from teaching and research institutions in France or abroad, or from public or private research centers.
L'archive ouverte pluridisciplinaire HAL, est destinée au dépôt et à la diffusion de documents scientifiques de niveau recherche, publiés ou non, émanant des établissements d'enseignement et de recherche français ou étrangers, des laboratoires publics ou privés. 


\title{
Coupled effects of aggregate size and alkali content on ASR expansion
}

\author{
S. Multon ${ }^{\mathrm{a}}$, M. Cyr ${ }^{\mathrm{a}, *}$, A. Sellier ${ }^{\mathrm{a}}$, N. Leklou ${ }^{\mathrm{a}}$, L. Petit $^{\mathrm{b}}$ \\ ${ }^{a}$ Laboratoire Matériaux et Durabilité des Constructions (EA3027) INSA-UPS, 135 Avenue de Rangueil, 31077 Toulouse Cedex 04, France \\ ${ }^{\mathrm{b}}$ Electricité de France (EDF)-Recherche et Développement, Avenue des Renardières, 77818 Moret sur Loing Cedex, France
}

\begin{abstract}
This work is a part of an overall project aimed at developing models to predict the potential expansion of concrete containing alkali-reactive aggregates. First, this paper reports experimental results concerning the effect of particle size of an alkali-reactive siliceous limestone on mortar expansion. Special attention is paid to the proportions of alkali $\left(\mathrm{Na}_{2} \mathrm{O}_{\mathrm{eq}}\right)$ in the mixtures and reactive silica in the aggregate. Results show that ASR expansion is seven times larger for coarse particles $(1.25-3.15 \mathrm{~mm})$ than for smaller ones $(80-160 \mu \mathrm{m})$. In mortars for which the two size fractions were used, ASR expansion increased in almost linear proportion to the amount of coarse reactive particles, for two different alkali contents. Then, an empirical model is proposed to study correlations between the measured expansions and parameters such as the size of aggregates and the alkali and reactive silica contents. Starting with the procedure for calibrating the empirical model using the experimental program combined with results from the literature, it is shown that the expansion of a mortar containing different sizes of reactive aggregate can be assessed with acceptable accuracy.
\end{abstract}

Keywords: Alkali-aggregate reaction; Particle size; Alkali content; Expansion; Model

\section{Introduction}

The work presented here is a part of an overall project to develop models to predict the potential expansion of concrete containing alkali-reactive aggregates. These models are intended to take account of several parameters, including the particle size of the reactive aggregates, the total amount of reactive silica and the alkali content of the mixture. In the literature, research on the size effect concerns several types of aggregates. It seems that the aggregate size causing the highest ASR expansion depended on the nature and composition of the aggregate. In spite of numerous investigations, it is difficult to generalize about the effect of the particle size of reactive aggregate, since conflicting results exist concerning the most damaging size which leads to the highest ASR expansion. Some authors obtained significant ASR expansions for very small particles [1], while others obtained insignificant expansion when the sizes of the reactive particles were less than 50 to $150 \mu \mathrm{m}[2-5]$. The use of powder from reactive aggregates like

\footnotetext{
* Corresponding author.

E-mail address: cyr@insa-toulouse.fr (M. Cyr).
}

pozzolans, with particle sizes up to about $100 \mu \mathrm{m}$, has even been developed to counteract the effect of ASR [6-8]. Other research works showed a pessimum effect for particles much larger than $100 \mu \mathrm{m}$ [1,2,9-11]. In most cases, the most damaging effect, leading to the highest ASR expansion, is reached for particle sizes larger than $1 \mathrm{~mm}$. All the results available in the literature were obtained using different experimental conditions. The apparent confusion remaining after this analysis can be related to the nature of reactive aggregates and/or to the different $\mathrm{Na} / \mathrm{Si}$ ratios of the mixtures, and the combined effect of size and alkali may be as important as the particle size effect alone.

This paper first gives experimental results on the effect on expansion of the particle size of an alkali-reactive siliceous limestone. Special attention is paid to the proportion of alkali $\left(\mathrm{Na}_{2} \mathrm{O}_{\text {eq }}\right)$ in the mixtures and reactive silica in the aggregate. A simple approach is then presented for the assessment of mortar expansion, based solely on correlation between the measured expansion and parameters such as the particle size of aggregates, and the alkali and reactive silica contents. Physicochemical interpretations of mechanisms and microstructural analyses are intentionally omitted, in order to highlight the 
Table 1

Chemical composition of cement and aggregates ( $\%$ by mass)

\begin{tabular}{|c|c|c|c|c|c|c|c|c|c|c|c|}
\hline & Fraction* & $\mathrm{SiO}_{2}$ & $\mathrm{Al}_{2} \mathrm{O}_{3}$ & $\mathrm{Fe}_{2} \mathrm{O}_{3}$ & $\mathrm{CaO}$ & $\mathrm{MgO}$ & $\mathrm{Na}_{2} \mathrm{O}$ & $\mathrm{K}_{2} \mathrm{O}$ & $\mathrm{Na}_{2} \mathrm{O}_{\text {eq }}$ & $\mathrm{SO}_{3}$ & LOI \\
\hline Cement & - & 20.1 & 5.6 & 2.0 & 62.5 & 3.1 & 0.2 & 0.9 & 0.8 & 3.2 & 1.7 \\
\hline Non-reactive marble & $\mathrm{F} 1, \mathrm{~F} 2, \mathrm{~F} 3$ & - & - & - & 54.4 & 0.49 & 0.001 & - & - & 0.01 & 43.0 \\
\hline \multirow[t]{2}{*}{ Reactive siliceous limestone } & $\mathrm{F} 1$ & 15.4 & 1.7 & 1.1 & 43.6 & 1.5 & 0.5 & 0.5 & 0.8 & 0.2 & 34.9 \\
\hline & F3 & 20.0 & 1.3 & 0.6 & 40.6 & 1.2 & 0.4 & 0.4 & 0.7 & 0.3 & 34.7 \\
\hline
\end{tabular}

*Size fraction of particles: F1 $(80-160 \mu \mathrm{m})$, F2 $(315-630 \mu \mathrm{m})$, F3 $(1.25-3.15 \mathrm{~mm})$.

empirical relationships between the macroscopic properties (expansion), particle size and silica content of reactive aggregate, and the alkali content. This approach is a first step to obtain a predictive model for ASR expansion.

\section{Experimental conditions}

\subsection{Materials}

The cement used was a standard CEM I 52.5R (specific gravity: 3.1 , surface area (Blaine): $400 \mathrm{~m}^{2} / \mathrm{kg}$ ). Its chemical composition is given in Table 1. The aggregates used were crushed sands: a non-reactive marble (NR) and a reactive siliceous limestone $(\mathrm{R})$. In order to control the particle size distribution of aggregates in the mortars, the aggregate samples were divided into three particle size fractions: F1 $(80-160 \mu \mathrm{m}), \mathrm{F} 2(315-630 \mu \mathrm{m})$ and F3 (1.25-3.15 mm). F1 was a fraction composed of fine particles, cut off at $80 \mu \mathrm{m}$ to limit the amount of very fine particles. Details of the aggregate combinations are given later.

The chemical composition of aggregates NR and $\mathrm{R}$ are given in Table 1. The non-reactive marble was almost exclusively composed of calcite. Previous work (unpublished data) had shown that this aggregate was not alkali-reactive. The reactive limestone contained mostly calcite and quartz, with traces of dolomite, feldspars and phyllosilicates. The finer size fraction (F1) contained less silica than the coarser (F3). This could be due to the difference of hardness between calcareous and silicate materials. Guédon et al. [12] showed that the silica component of this aggregate had a high potential for ASR and was present as fine grains dispersed through the calcite matrix.

\subsection{Methods}

\subsubsection{Soluble silica}

Quantification of the soluble silica in each fraction (F1 and F3) of the reactive aggregate was performed by selective dissolution. The first step consisted of digesting the aggregate in $\mathrm{HCl}$ in order to dissolve the limestone and thus concentrate the reactive part of the aggregate. 100-g samples of each fraction of aggregate (F1 and F3) were crushed and dissolved separately in $750 \mathrm{ml}$ of $\mathrm{HCl}(2.3 \mathrm{M})$ at $20{ }^{\circ} \mathrm{C}$ for half an hour. After being filtrated, washed and dried at $105{ }^{\circ} \mathrm{C}$, the residue was weighed and analyzed by X-ray diffraction. The quantitative analysis confirmed the chemical composition for calcite: around 78\% and $72 \%$ for $\mathrm{F} 1$ and $\mathrm{F} 3$, respectively. The acid-insoluble residue of the aggregate was composed of quartz, feldspars and phyllosilicates. Amorphous phases are not detected by XRD. It should be noted that a control measurement (atomic absorp- tion) showed that only $0.02 \%$ of the total amount of silica was dissolved during the acid attack.

The second step of the dissolution was performed on the siliceous residue and consisted of a basic attack by $\mathrm{NaOH}$. Three-gram samples of non-calcareous residue were placed in closed stainless steel vessels containing $40 \mathrm{~g}$ of a $1.62 \mathrm{M} \mathrm{NaOH}$ solution. This concentration was chosen to approach the highest amount of alkali added to our mortars $\left(13.4 \mathrm{~kg} / \mathrm{m}^{3}\right)$. The sealed vessels were kept under water maintained at $60{ }^{\circ} \mathrm{C}$ in a thermostatically controlled bath (same temperature as our tests on mortars). At each measurement date (3, 7, 13, 20, 27, 34 and 104 days), a $3 \mathrm{ml}$ portion of solution was sampled from the vessels with a syringe and filtered. Three $\mathrm{ml}$ of the initial $\mathrm{NaOH}$ solution was added to the vessels to replace the sampled solution. The $\mathrm{pH}$ of the sample solutions was measured before they were analyzed by flame spectrometry for silica and alkali. Corrections were made to take account of the dilution in the vessels. Two series of tests were performed, one on aggregate size F1 and one on F3, and were repeated three times.

\subsubsection{ASR expansion measurements}

Expansion was measured on mortar prisms $(2 \times 2 \times 16 \mathrm{~cm})$ with a water-cement ratio of 0.5 and sand $\left(1613.4 \mathrm{~kg} / \mathrm{m}^{3}\right)$ to cement $\left(537.8 \mathrm{~kg} / \mathrm{m}^{3}\right)$ ratio of 3 . In order to achieve two distinct $\mathrm{Na} / \mathrm{Si}$ ratios, mixtures were adjusted to alkali contents $\left(\mathrm{Na}_{2} \mathrm{O}_{\text {eq }}\right)$ of 6.2 and $13.4 \mathrm{~kg}$ of alkali per $\mathrm{m}^{3}$ of mortar by adding $\mathrm{NaOH}$ in the mixing water. An alkali-free superplasticizer was used $(0.5 \%$ dry matter of cement mass) in mortars to achieve a proper set in the molds.

Aggregates in all mortars had an equivalent particle size distribution and were composed of $30 \%$ of $\mathrm{F} 1,40 \%$ of $\mathrm{F} 2$ and $30 \%$ of F3. Six mortar mixtures were studied, with different proportions of reactive and non-reactive aggregates from the three size fractions F1 to F3 (Table 2). Only fractions F1 and F3 were used as reactive aggregates in order to study reactive particle sizes which were significantly different.

Table 2

Grading of aggregates of mortar mixtures

\begin{tabular}{|c|c|c|c|c|c|c|}
\hline \multirow{3}{*}{$\frac{\text { Size fraction }}{\text { Nature }}$} & \multicolumn{6}{|c|}{ Weight fraction (\%) of the sand } \\
\hline & \multicolumn{2}{|c|}{ F1 $(80-160 \mu \mathrm{m})$} & \multicolumn{2}{|c|}{ F2 $(315-630 \mu \mathrm{m})$} & \multicolumn{2}{|c|}{ F3 $(1.25-3.15 \mathrm{~mm}$} \\
\hline & $\mathrm{R}$ & NR & $\mathrm{R}$ & NR & $\mathrm{R}$ & NR \\
\hline Reference & 0 & 30 & 0 & 40 & 0 & 30 \\
\hline M1 & 0 & 30 & 0 & 40 & 30 & 0 \\
\hline M2 & 5 & 25 & 0 & 40 & 25 & 5 \\
\hline M3 & 15 & 15 & 0 & 40 & 15 & 15 \\
\hline M4 & 25 & 5 & 0 & 40 & 5 & 25 \\
\hline M5 & 30 & 0 & 0 & 40 & 0 & 30 \\
\hline
\end{tabular}


The mortar prisms were kept in sealed bags at $20{ }^{\circ} \mathrm{C}$ for 27 days after demoulding, i.e. $24 \mathrm{~h}$ after casting. The prisms were stored at $60{ }^{\circ} \mathrm{C}$, placed on grids in watertight containers containing $20 \mathrm{~mm}$ of water (mortar bars were not in contact with water) 28 days after mixing. Salt $\left(\mathrm{K}_{2} \mathrm{SO}_{4}\right)$ was added to the water in order to maintain a relative humidity above $95 \%$ in the containers and to try to avoid condensation. Expansion was measured using the scale micrometer method (specimens had shrinkage bolts in the two extremities). Each length change value reported is the mean of three values from three replicate specimens. Expansion measurements were performed after the containers and the prisms had been cooled for $24 \mathrm{~h}$ at $20^{\circ} \mathrm{C}$.

\section{Experimental results}

\subsection{Soluble silica}

The dissolution curves of silica up to 104 days are given in Fig. 1 for size fractions F1 and F3. Both curves reached asymptote values, at dissolved silica $\left(\mathrm{SiO}_{2}\right)$ values of $9.4 \%$ and $12.4 \%$ of the total mass of reactive aggregate for fractions $\mathrm{F} 1$ and $\mathrm{F} 3$ respectively. These results are in accordance with that found by Poyet $(11.1 \%)$ on a similar aggregate from the same source [13]. It should be noted that the total silica contents were $15.4 \%$ for fractions F1 and $20.0 \%$ for F3 (Table 1). A similar variation is noted in the amount of dissolved silica between particles of different sizes; the coarser aggregate showing a higher soluble silica content. The ratios $\mathrm{SiO}_{2-\mathrm{F} 1} / \mathrm{SiO}_{2-\mathrm{F} 3}$ for the total silica content $(15.4 / 20.0=0.77)$ and for the dissolved silica $(9.4 / 12.4=0.76)$ are almost the same. The measurement of dissolved silica, as performed here, probably gave the minimum values of the total amount of silica available for ASR, since it did not take into account the possible precipitation of a limited fraction of the silica present in the solution [14-16].

\subsection{ASR expansion}

When mortar specimens are maintained in a hot and saturated atmosphere $\left(60^{\circ} \mathrm{C}\right.$, R.H. $\left.>95 \%\right)$, a part of the expansion over time is related to the ambient conditions. Thus, the ASR-expansions presented in this paper were obtained by subtracting the expansion of the reference mortar (without reactive aggregate) from

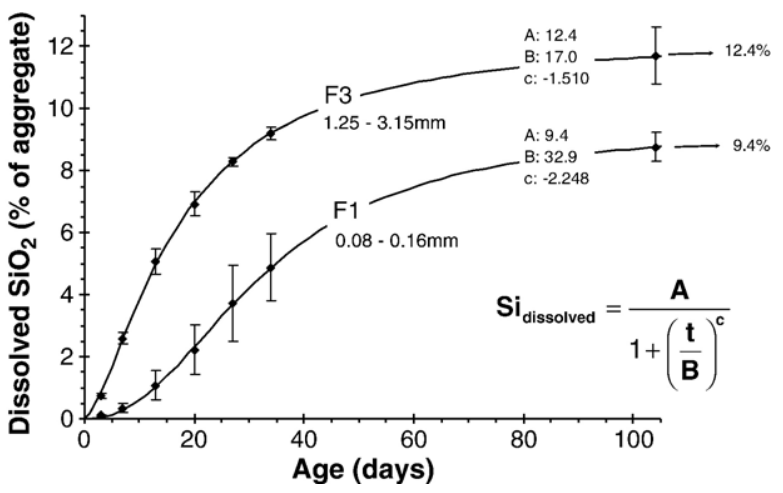

Fig. 1. Dissolved silica as a function of time, presented in percent of the total aggregate mass, for the two size fractions of aggregate F1 and F3.

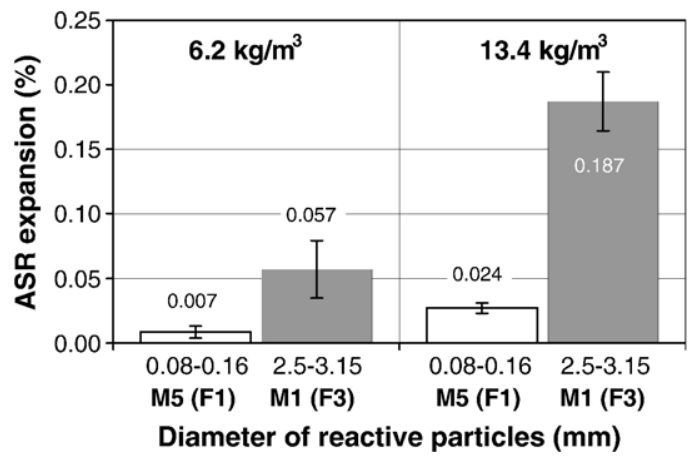

Fig. 2. Effect of particle size of reactive aggregate on mortar expansion (M5 and M1).

the total expansion, as already proposed by some authors [17-19]. This approach is justified since the aggregate is completely nonreactive (chemical analysis - Table 1). The long-term expansions of the two reference mortars were $0.036 \%$ and $0.043 \%$ for low and high alkali contents respectively.

\subsubsection{Effect of particle size on mortar expansion}

Fig. 2 shows the final ASR expansion (after about 150 days at $60{ }^{\circ} \mathrm{C}$ ) of mixtures containing only reactive particles from size fractions F1 and F3 (mortars M5 and M1). For the two alkali contents and for the same amount of reactive aggregate in the mortars, the expansion decreased by about $90 \%$ when aggregate fraction F1 was used $(0.08-0.16 \mathrm{~mm})$ instead of aggregate fraction F3 $(1.25-3.15 \mathrm{~mm})$. The sole difference in soluble silica between fractions F1 (9.4\%) and F3 (12.4\%) cannot easily explain these variations of expansion.

To the authors' knowledge, only a few results concerning the effect of particle size of siliceous limestone on the ASR expansion are available in the literature. The tests of Hasni et al. [5] and Poyet [13] were performed on a similar siliceous limestone to the one used in this study. Their results confirm those presented here, i.e., the larger the aggregate, the higher the expansion of mortar prisms.

Fig. 3 shows the final ASR expansion (after about 150 days at $60{ }^{\circ} \mathrm{C}$ ) related to the amount of coarse (and fine) reactive particles in mortar mixtures. The expansion increased proportionally to the amount of coarse reactive particles in the mortars,

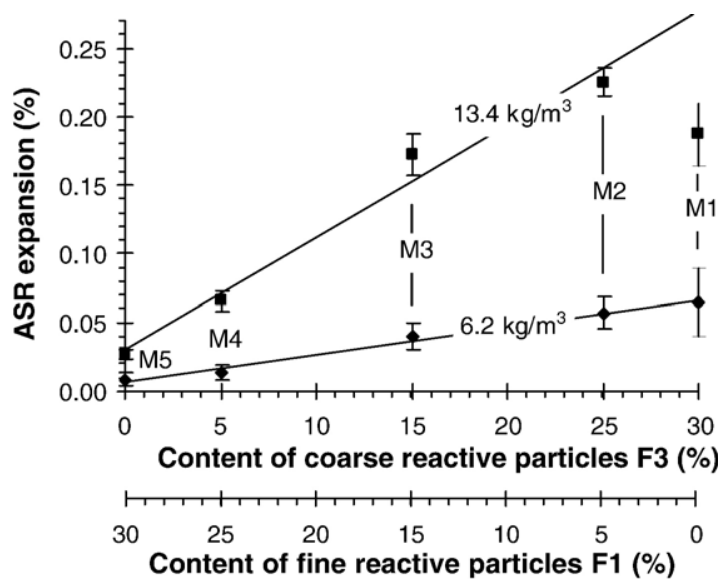

Fig. 3. ASR expansion of mortar prisms made of $30 \%$ of reactive aggregate taken from size fractions F1 and F3. 
and a linear trend was assumed. Thus, the results presented in Fig. 3 for this aggregate show an additivity of the expansion, related to the amount of the two particle size fractions (F1 and F3) used in the mortar mixture (Eq. (1)). For example, for the lowest alkali content, the expansion of mortars M3 is the mean of the expansion values of mortars M1 and M5.

$\varepsilon_{\mathrm{M} 3}=\frac{p_{3}}{p_{3}+p_{1}} \cdot \varepsilon_{\mathrm{M} 1}+\frac{p_{1}}{p_{3}+p_{1}} \cdot \varepsilon_{\mathrm{M} 5}$

where $p_{3}$ and $p_{1}$ are the percentages of coarse and fine reactive particles respectively in the mortar, $\varepsilon_{\mathrm{M} 1}, \varepsilon_{\mathrm{M} 3}$ and $\varepsilon_{\mathrm{M} 5}$ are the expansion values of mortars M1, M3 and M5 (M1 and M5 respectively, containing only coarse and fine reactive particles).

Only mixture M1 with $13.4 \mathrm{~kg} / \mathrm{m}^{3}$ of alkali did not follow the linear trend. In order to assess the scattering of the results, water porosity measurements were carried out on all mortars. The porosity lied in the ranges $16.9-17.9 \%$ and $17.8-20.7 \%$ for the low and high alkali contents, respectively. The heterogeneity of expansion values may be explained by this scattering. For the highest alkali content, the largest porosity was measured for mortar M1, which can also explain the lower expansions observed for these specimens compared to mortar M2. It can be noted that the expansion is completely proportional to the amount of coarse reactive particle for the lowest alkali content. The authors have chosen to keep the assumption of a linear trend in their calculations. As shown in the next part, calculations based on this assumption are rather acceptable.

\subsubsection{Effect of alkali content on ASR expansion}

It is generally admitted that there is an important effect of the alkali content on ASR expansion. In this study, a decrease of about 70 to $80 \%$ of the expansion was obtained when the alkali content of mortar mixtures was reduced from the higher $\left(13.4 \mathrm{~kg} / \mathrm{m}^{3}\right)$ to the lower value $\left(6.2 \mathrm{~kg} / \mathrm{m}^{3}\right)$. Many authors propose a threshold effect of alkali, generally between 3 and $5 \mathrm{~kg}$ of alkali per $\mathrm{m}^{3}$ of concrete [20-24], below which ASR expansion is small. Fig. 4 presents the ASR-expansion of our mortars as a function of their alkali content. In the case of this study, a linear relationship was assumed between the expansion and the alkali content. Thus, the results for mortar prisms M1 to M5 lead to a threshold value to be defined for alkali content, ranging between 2.9 and $4.4 \mathrm{~kg} / \mathrm{m}^{3}$ with a mean value of $3.7 \mathrm{~kg} / \mathrm{m}^{3}$. This threshold value, which does not

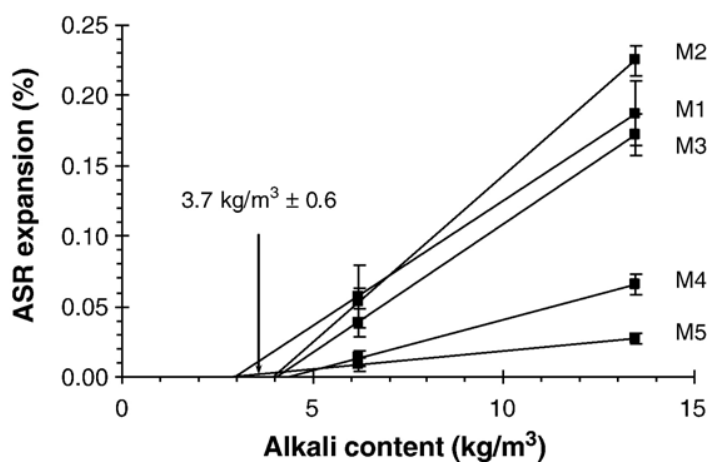

Fig. 4. Effect of the alkali contents on expansions of mortars M1 to M5. contradict those found in the literature, will be used in the empirical model presented in this paper.

\section{Development of an empirical model}

A model is proposed to interpret our results (and others found in the literature) and to describe the relationship between the amount of alkali and reactive silica, and the final ASR expansion for mortar cast with reactive siliceous limestone. In a first phenomenological approach, an empirical model has been developed. It is based only on correlations between experimental data. In order to estimate the ASR expansion, the model uses the total amount of alkali in the mortar $\left(A_{\mathrm{T}}\right.$ in Fig. 5), the size fraction of the reactive aggregates (subscript $i$ in Fig. 5, for size fractions 1 or 3 ), and the available silica obtained from a basic attack of the aggregates $\left(s_{i} \cdot p_{i}-\right.$ Fig. 5). These parameters were considered as the most important parameters for specimens subjected to ASR and kept in similar moisture conditions. This empirical model does not consider the kinetics of expansion or the complex physical and chemical phenomena responsible for ASR, but only the final expansion. Obviously, the authors are aware that this approach is a simplification of reality.

\subsection{Principle of the model}

This part presents the principle and the different steps in the calculations, which are summarized in Fig. 5. The two main steps are (i) calculation of the amount of alkali which would react to form ASR gel (Section 4.1.1), and (ii) determination of ASR expansion (Section 4.1.2), based on the ASR expansion of each size fraction (F1 and F3) at this amount.

\subsubsection{Determination of the amount of alkali consumed $A_{C i}$}

One of the main assumptions of the model is that the maximum expansion of mortar is achieved if there is enough alkali to react with all the reactive silica of the mixture. This amount of alkali is called the "amount of required alkali" ( $A_{\mathrm{R} i}$ - first column of the flow chart in Fig. 5) and is equal for each fraction to:

$A_{\mathrm{R} i}=r \times s_{i} \times p_{i} \times \mathrm{SC}$

where $r$ is the ratio of required alkali per $\mathrm{kg}$ of reactive silica (calculated in Section 4.2.1 by using the experimental results of Poyet [13]), $s_{i}$ the quantity of soluble silica in the fraction $F_{i}, p_{i}$, the proportion of reactive aggregate of the fraction $F_{i}$ in the mortar and $\mathrm{SC}$, the total sand content.

The present analysis assumes that a part of the total available alkali $\left(A_{\mathrm{T}}\right)$ is consumed to reach a threshold of alkali per $\mathrm{m}^{3}$ of mortar $\left(A_{0}\right)$ necessary to initiate ASR expansion. With the assumption of linear relationship between expansion and alkali content, our own results led to a threshold $A_{0}$ of $3.7 \mathrm{~kg} / \mathrm{m}^{3}$ for this reactive aggregate (Fig. 4).

The amount of alkali $A_{0}$ is assumed to be unavailable for ASR-expansion development, and only the remainder amount of available alkali $\left(A_{\mathrm{A}}\right)$ is taken into account for the calculation of expansions (Eq. (3)). For a fraction $F_{i}$, the amount of available alkali $A_{\mathrm{A} i}$ (Eq. (4)) is assumed to be proportional to 


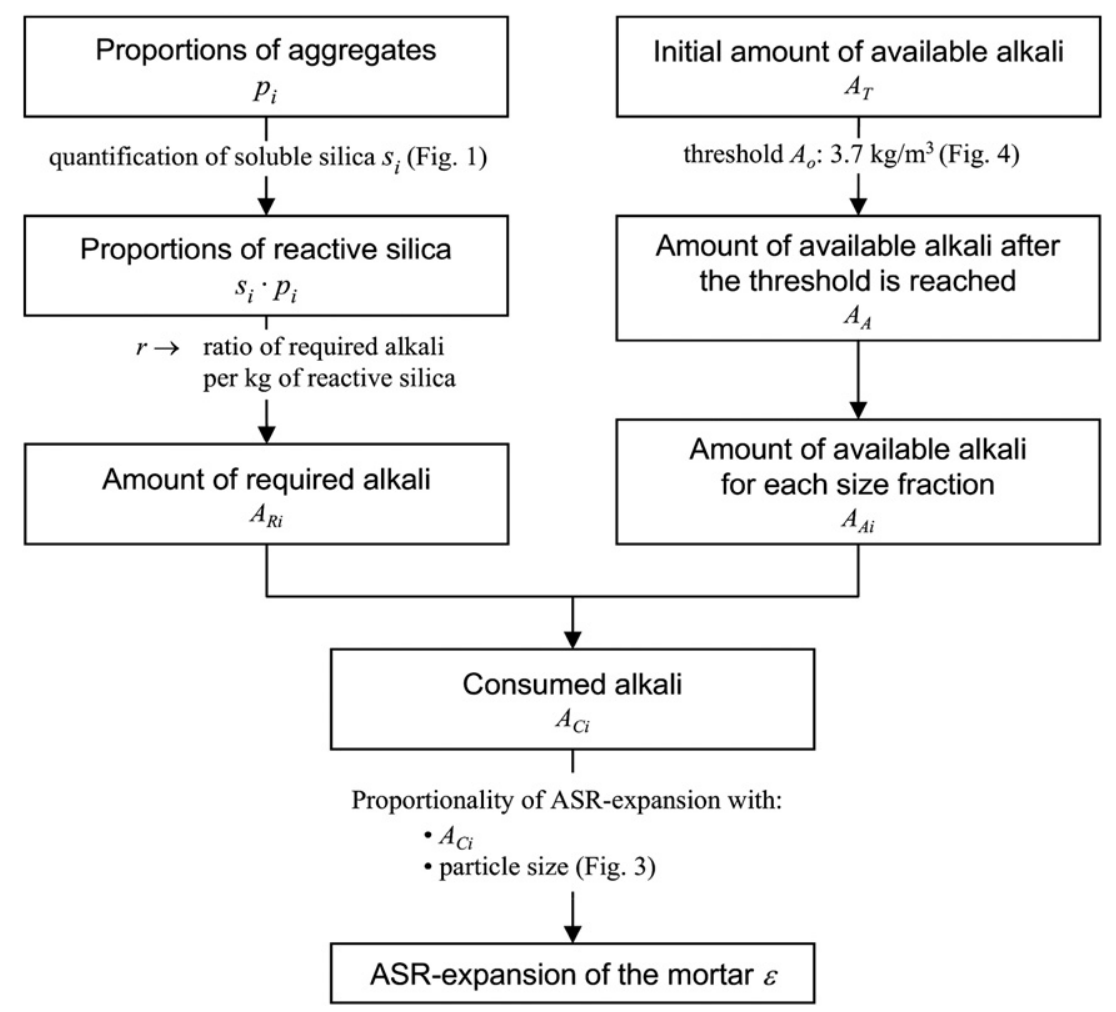

Fig. 5. Steps of the empirical model. Subscript $i$ is relative to a single size fraction.

the amount of alkali available in the mortar and to the reactive silica content contained in fraction $F_{i}$ :

$A_{\mathrm{A}}=A_{\mathrm{T}}-A_{0}$

$A_{\mathrm{A} i}=\frac{s_{i} \times p_{i}}{\sum_{i}\left(s_{i} \times p_{i}\right)} \times A_{\mathrm{A}}$

The model assumes that if $A_{\mathrm{A} i} \geq A_{\mathrm{R} i}$ (more alkali available than required for the maximum expansion), then the expansion is maximum. If $A_{\mathrm{A} i}<A_{\mathrm{R} i}$ (not enough alkali available compared to alkali required for the maximum expansion), then the expansion is proportional to $A_{\mathrm{A} i} / A_{\mathrm{R} i}$ (ratio of available and required alkali). The amount of alkali consumed by the reaction $\left(A_{\mathrm{C} i}\right)$ is taken to be equal to the amount of available alkali $A_{\mathrm{A} i}$, but cannot be greater than $A_{\mathrm{R} i}$ :

$A_{\mathrm{C} i}=\inf \left(A_{\mathrm{A} i}, A_{\mathrm{R} i}\right)$

To sum up, the role of the alkali is described in two steps:

- Significant ASR expansion begins when alkali content is higher than the threshold $A_{0}\left(3.7 \mathrm{~kg} / \mathrm{m}^{3}\right)$. The amount of alkali available for the alkali-silica reaction $\left(A_{\mathrm{A}}\right)$ is the total amount of alkali in the mixture minus the threshold amount.

- If the amount of available alkali for fraction $F_{i}\left(A_{\mathrm{A} i}\right)$ is greater than the amount of required alkali $\left(A_{\mathrm{R} i}\right)$, then the ASR expansion of the fraction would be maximal. If $A_{\mathrm{R} i}$ is not reached, then ASR expansion would be proportional to the ratio $A_{\mathrm{A} i} / A_{\mathrm{R} i}$.

\subsubsection{Determination of ASR expansion}

Each particle size fraction (F1 and F3) of reactive aggregate was characterized by an ASR expansion. In addition, Fig. 3 allows a linear trend to be found between ASR expansions and the amount of coarse reactive particles. Therefore, the analysis is based on the following assumption: ASR expansion of mixtures of reactive particle size fractions is proportional to the amounts and to the ASR expansions of the particle size fractions (Eq. (1)). Thus, the calculated expansion $\left(\varepsilon_{\mathrm{cal}}\right)$ can be obtained from Eq. (6).

$\varepsilon_{\mathrm{cal}}=\sum_{i} s_{i} \times p_{i} \times S C \times \varepsilon_{i} \times \frac{A_{\mathrm{C} i}}{A_{\mathrm{R} i}}$

where $\varepsilon_{i}$ is the maximal ASR expansion per $\mathrm{kg}$ of reactive silica of a mortar having an excess of alkali and containing only reactive particles of fraction $F_{i}$.

\subsection{Calibration of the model}

\subsubsection{Determination of the amount of required alkali per $\mathrm{kg}$ of reactive silica}

The amount of required alkali per $\mathrm{kg}$ of reactive silica ( $r$ in Fig. 5) is the amount of required alkali that causes the maximal ASR expansion of mortar containing $1 \mathrm{~kg}$ of reactive silica. This ratio was determined by using results found in the literature, especially the experimental work of Poyet [13] on the same kind of mixtures (same cement, water and sand contents) in the same storage conditions, with a similar reactive aggregate (total reactive silica content of $11.1 \%$ ) and with a total alkali content of $12.9 \mathrm{~kg} / \mathrm{m}^{3}$. The sand was composed of the three particle size 
Table 3

Mixtures and ASR expansions of mortars studied by Poyet [13]

\begin{tabular}{|c|c|c|c|c|c|c|c|}
\hline \multirow[b]{2}{*}{ Mixture } & \multicolumn{3}{|c|}{$\begin{array}{l}\text { Non-reactive } \\
\text { sand }(\%)\end{array}$} & \multicolumn{3}{|c|}{$\begin{array}{l}\text { Reactive } \\
\text { sand (\%) }\end{array}$} & \multirow{2}{*}{$\begin{array}{l}\text { Measured ASR expansion } \\
(\%)\end{array}$} \\
\hline & $\mathrm{F} 1$ & $\mathrm{~F} 2$ & F3 & F1 & F2 & F3 & \\
\hline M1 & 0 & 50 & 25 & 25 & 0 & 0 & 0.003 \\
\hline M2 & 25 & 25 & 25 & 0 & 25 & 0 & 0.06 \\
\hline M3 & 25 & 50 & 0 & 0 & 0 & 25 & 0.06 \\
\hline M1M2 & 0 & 25 & 25 & 25 & 25 & 0 & 0.045 \\
\hline M2M3 & 25 & 25 & 0 & 0 & 25 & 25 & 0.08 \\
\hline
\end{tabular}

fractions in Table 3. ASR expansion was measured on five mortars: M1 containing $25 \%$ of F1, M2 containing $25 \%$ of F2, M3 containing $25 \%$ of F3, M1M2 containing $25 \%$ of $\mathrm{F} 1$ and $25 \%$ of $\mathrm{F} 2$, and M2M3 containing $25 \%$ of $\mathrm{F} 2$ and $25 \%$ of F3 (Table 3).

The original analysis of these experimental results, presented below, was carried out in three steps:

1. Analysis of ASR expansion measured for M2, M3 and M2M3.

ASR expansion values measured on M2 and M3 were both equal to $0.06 \%$ (Table 3 ). By using the assumption of linearity of the expansions with the amount of reactive particles (Fig. 3), ASR expansion of mortar M2M3 should be equal to $0.06 \%+$ $0.06 \%=0.12 \%$, but only $0.08 \%$ was measured. One explanation of such a result could be a lack of alkali in the M2M3 mixture. This assumption was used to determine the amount of required alkali per $\mathrm{kg}$ of reactive silica.

2. Calculation of the amount of required alkali $\left(A_{\mathrm{R} i}\right)$ to obtain maximal expansion of M2M3 mortar.

The initial available alkali content $\left(A_{T}\right)$ in Poyet's experiments was $12.9 \mathrm{~kg} / \mathrm{m}^{3}$. In our model, the role of alkali is described in two steps (second column of the flow chart Fig. 5).

(a) First the threshold of $3.7 \mathrm{~kg}$ alkali per $\mathrm{m}^{3}$ of concrete $\left(A_{0}\right)$ must be reached before any significant expansion occurs. For the M2M3 mixture, the amount of available alkali was 12.9$3.7=9.2 \mathrm{~kg} / \mathrm{m}^{3}$ (Eq. (3)).

In our model, it is assumed that ASR expansion is not maximal (as observed for the mortar M2M3, 0.08\% versus $0.12 \%$ ) because the amount of required alkali is not reached. Thus, the total amount of alkali consumed by the two fractions of reactive aggregate is equal to the amount of available alkali $\left(A_{\mathrm{C}}=A_{\mathrm{A}}=9.2 \mathrm{~kg} / \mathrm{m}^{3}\right)$.

(b) Then our model assumes proportionality between the amount of consumed alkali and the expansion. For the M2M3 mixture, the expansion was $0.08 \%$. So, considering that the expected expansion of M2M3 mortar is $0.12 \%$, the amount of required alkali $\left(A_{\mathrm{R} i}\right)$ to obtain maximal expansion of M2M3 is given by:

$\frac{A_{\mathrm{R}}}{\varepsilon_{\mathrm{M} 2}+\varepsilon_{\mathrm{M} 3}}=\frac{A_{\mathrm{C}}}{\varepsilon_{\mathrm{M} 2 \mathrm{M} 3}} \rightarrow \frac{A_{\mathrm{R}}}{0.12 \%}=\frac{9.2 \mathrm{~kg} / \mathrm{m}^{3}}{0.08 \%} \rightarrow A_{R}=13.8 \mathrm{~kg} / \mathrm{m}^{3}$

Thus, the amount of required alkali $\left(A_{\mathrm{R}}\right)$ to obtain the maximal expansion of M2M3 mortar would be $13.8 \mathrm{~kg} / \mathrm{m}^{3}$.
3. Calculation of the amount of required alkali per $\mathrm{kg}$ of reactive silica $(r)$.

The reactive aggregate in Poyet's experiments [13] contained $11.1 \%$ of reactive silica and mortar M2M3 contained $50 \%$ of reactive aggregate (with a total sand content, SC, of $1613.4 \mathrm{~kg} / \mathrm{m}^{3}$ ). So the content of reactive silica in M2M3 mortar was $11.1 \% \times 50 \% \times 1613.4=89.5 \mathrm{~kg}$ per $\mathrm{m}^{3}$ of mortar. Therefore, in order to obtain the maximal expansion of all the reactive silica, the amount of required alkali per $\mathrm{kg}$ of reactive silica must be equal to $r=13.8 / 89.5=15.4 \%$ by mass of reactive silica.

\subsubsection{First check}

The first check on the empirical model used mortar M1M2 from Poyet's study [13]. Calculations are presented in Fig. 6. The ASR expansions measured for the mortars M1 and M2 were $0.003 \%$ and $0.06 \%$, respectively (Table 3 ). The ASR expansion of M1M2 was $0.045 \%$, lower than the sum of the expansions of M1 and M2 (0.063\%). As for M2M3, mortar M1M2 contained $50 \%$ of reactive particles. The amount of required alkali $\left(A_{\mathrm{R} i}\right)$ to obtain the total expansion of all the reactive particles of each particle size fraction $F_{i}$ is given by Eq. (2).

In Poyet's experiments [13], the proportion of reactive silica $\left(s_{i}\right)$ was $11.1 \%$ by mass of coarse particles. As observed in our experiment, it was assumed that the fine particles contained $25 \%$ less reactive silica than the coarse ones. So the amount of alkali required to dissolve all the silica was:

- for fraction F1: $A_{R 1}=15.4 / 100 \times 75 / 100 \times 11.1 / 100 \times 25 / 100 \times$ $1613.4=5.2 \mathrm{~kg} / \mathrm{m}^{3}$

- for fraction F2: $A_{R 2}=15.4 / 100 \times 11.1 / 100 \times 25 / 100 \times 1613.4=$ $6.9 \mathrm{~kg} / \mathrm{m}^{3}$.

For the M1M2 mixture, the amount of available alkali was $12.9-3.7=9.2 \mathrm{~kg} / \mathrm{m}^{3}$. So the amount of available alkali for $\mathrm{F} 1$ and F2 was calculated from Eq. (4):

$$
\begin{aligned}
& A_{A 1}=\frac{75 / 100 \times 11.1 / 100 \times 25 / 100}{(75 / 100 \times 11.1 / 100+11.1 / 100) \times 25 / 100} \times 9.2 \mathrm{~kg} / \mathrm{m}^{3}=3.9 \mathrm{~kg} / \mathrm{m}^{3} \\
& A_{A 2}=\frac{11.1 / 100 \times 25 / 100}{(75 / 100 \times 11.1 / 100+11.1 / 100) \times 25 / 100} \times 9.2 \mathrm{~kg} / \mathrm{m}^{3}=5.3 \mathrm{~kg} / \mathrm{m}^{3}
\end{aligned}
$$

In fact, the amount of alkali consumed in the reaction $\left(A_{\mathrm{C} i}\right)$ was equal to the amount of available alkali but cannot be larger than the amount of required alkali (Eq. (5)):

$$
\begin{aligned}
& A_{\mathrm{C} 1}=\inf \left(5.2 \mathrm{~kg} / \mathrm{m}^{3}, 3.9 \mathrm{~kg} / \mathrm{m}^{3}\right)=3.9 \mathrm{~kg} / \mathrm{m}^{3} \\
& A_{\mathrm{C} 2}=\inf \left(6.9 \mathrm{~kg} / \mathrm{m}^{3}, 5.3 \mathrm{~kg} / \mathrm{m}^{3}\right)=5.3 \mathrm{~kg} / \mathrm{m}^{3}
\end{aligned}
$$

The ASR expansion of mortar M1M2 was the sum of the ASR expansions of each fraction proportionally to the reactive particle content, to $A_{\mathrm{C} i} / A_{\mathrm{R} i}$ and to ratio $\varepsilon_{i}$ (Eq. (6)). For Poyet's 


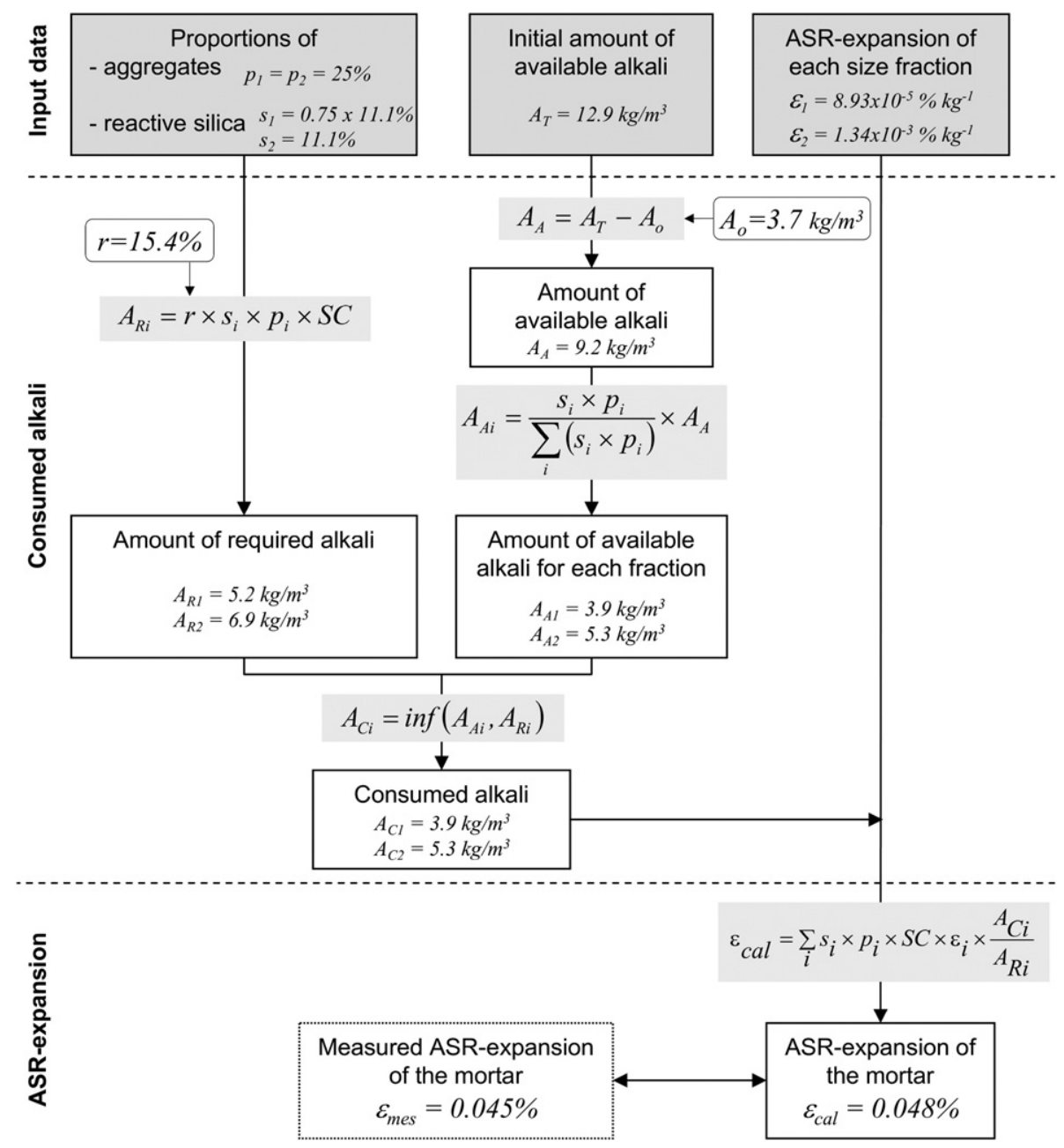

Fig. 6. Principle and equation of the empirical model. The input data and calculated values concern mortar M1M2.

experiment $\varepsilon_{i}$ was assessed from the measured ASR expansion (Eq. (7)).

$\varepsilon_{i}=\frac{\varepsilon_{\mathrm{F} i}}{s_{i} \times p_{i} \times \mathrm{SC}}$

where $\varepsilon_{\mathrm{F} i}$ is the measured ASR expansion of the mortar containing reactive particles of fraction $F_{i}$ only. In Poyet's study, $\varepsilon_{\mathrm{F} 1}$ was measured on mortar M1 $(75 \% \times 11.1 \% \times 25 \% \times$ $1613.4 \mathrm{~kg} / \mathrm{m}^{3}$ of $\left.\mathrm{F} 1\right)$ and $\varepsilon_{\mathrm{F} 2}$ was measured on mortar M2 $\left(11.1 \% \times 25 \% \times 1613.4 \mathrm{~kg} / \mathrm{m}^{3}\right.$ of $\left.\mathrm{F} 2\right)$ :

$\varepsilon_{1}=\frac{0.003 \%}{75 \% \times 11.1 \% \times 25 \% \times 1613.4}=8.93 \cdot 10^{-5} \% . \mathrm{kg}^{-1}$

$\varepsilon_{2}=\frac{0.06 \%}{5.2 \% \times 25 \% \times 1613.4}=1.34 \cdot 10^{-3} \% \cdot \mathrm{kg}^{-1}$

Thus, the expansion predicted by the model $\left(\varepsilon_{\mathrm{cal}}\right)$ can be obtained from Eq. (6):

$$
\begin{aligned}
\varepsilon_{\mathrm{cal}}(\mathrm{M} 1 \mathrm{M} 2)= & 11.1 \% \times 25 \% \times 1613.4 \\
& \times\left(75 \% \times 8.93 \cdot 10^{-5} \times \frac{3.9 \mathrm{~kg} / \mathrm{m}^{3}}{5.2 \mathrm{~kg} / \mathrm{m}^{3}}+1.34 \cdot 10^{-3} \times \frac{5.3 \mathrm{~kg} / \mathrm{m}^{3}}{6.9 \mathrm{~kg} / \mathrm{m}^{3}}\right) \\
= & 0.048 \%
\end{aligned}
$$

The difference between this calculated expansion and the measured ASR expansion $(0.045 \%$ - Table 3$)$ is less than $10 \%$. In this case, it confirms the possibility of calculating the expansion of mortars containing different reactive particle size fractions by using the expansion of each reactive particle size fraction and the amount of alkali as input data.

\subsubsection{Summary}

The principle and the equations are summarized in Fig. 6. The input data and calculated values are also given for mortar M1M2. As shown in this flow chart, ASR expansion of mortar can be assessed from three main input data: the amount of reactive silica (according to the proportion of reactive aggregate in the mortar), the total amount of available alkali and the ASR expansion of each size fraction.

\subsection{Application of the empirical model}

The model is now used to interpret the experimental results presented in the first part of the paper. In the experiment, the sand was composed of two reactive particle size fractions: F1 $(80-160 \mu \mathrm{m})$ and F3 $(1.25-3.15 \mathrm{~mm})$. 
Determination of the amount of consumed alkali in different mortar mix

\begin{tabular}{|c|c|c|c|c|c|c|c|c|c|c|c|c|c|}
\hline & & 1 & 2 & 3 & 4 & 5 & 6 & 7 & 8 & 9 & 10 & 11 & 12 \\
\hline & & $p_{1}$ & $p_{3}$ & $s_{1}$ & $s_{3}$ & $A_{\mathrm{R} 1}$ & $A_{\mathrm{R} 3}$ & $A_{0}$ & $A_{\mathrm{A}}$ & $A_{\mathrm{A} 1}$ & $A_{\mathrm{A} 3}$ & $A_{\mathrm{C} 1}$ & $A_{\mathrm{C} 3}$ \\
\hline & & $\%$ & $\overline{\%}$ & $\overline{\%}$ & $\%$ & $\mathrm{~kg} / \mathrm{m}^{3}$ & $\mathrm{~kg} / \mathrm{m}^{3}$ & $\mathrm{~kg} / \mathrm{m}^{3}$ & $\mathrm{~kg} / \mathrm{m}^{3}$ & $\mathrm{Kg} / \mathrm{m}^{3}$ & $\mathrm{~kg} / \mathrm{m}^{3}$ & $\mathrm{~kg} / \mathrm{m}^{3}$ & $\mathrm{~kg} / \mathrm{m}^{3}$ \\
\hline \multirow[t]{5}{*}{$6.2 \mathrm{~kg} / \mathrm{m}^{3} \mathrm{Na}_{2} \mathrm{O}_{\mathrm{eq}}$} & M1 & 0 & 30 & 9.4 & 12.4 & 0.00 & 9.26 & 6.18 & 2.48 & 0.00 & 2.48 & 0.00 & 2.48 \\
\hline & M2 & 5 & 25 & 9.4 & 12.4 & 1.20 & 7.71 & 6.18 & 2.48 & 0.33 & 2.16 & 0.33 & 2.16 \\
\hline & M3 & 15 & 15 & 9.4 & 12.4 & 3.51 & 4.63 & 6.18 & 2.48 & 1.07 & 1.41 & 1.07 & 1.41 \\
\hline & M4 & 25 & 5 & 9.4 & 12.4 & 5.85 & 1.54 & 6.18 & 2.48 & 1.97 & 0.52 & 1.97 & 0.52 \\
\hline & M5 & 30 & 0 & 9.4 & 12.4 & 7.02 & 0.00 & 6.18 & 2.48 & 2.48 & 0.00 & 2.48 & 0.00 \\
\hline \multirow{5}{*}{$13.4 \mathrm{~kg} / \mathrm{m}^{3} \mathrm{Na}_{2} \mathrm{O}_{\mathrm{eq}}$} & M1 & 0 & 30 & 9.4 & 12.4 & 0.00 & 9.26 & 13.45 & 9.75 & 0.00 & 9.75 & 0.00 & 9.26 \\
\hline & M2 & 5 & 25 & 9.4 & 12.4 & 1.20 & 7.71 & 13.45 & 9.75 & 1.28 & 8.46 & 1.17 & 7.71 \\
\hline & M3 & 15 & 15 & 9.4 & 12.4 & 3.51 & 4.63 & 13.45 & 9.75 & 4.20 & 5.54 & 3.51 & 4.63 \\
\hline & M4 & 25 & 5 & 9.4 & 12.4 & 5.85 & 1.54 & 13.45 & 9.75 & 7.71 & 2.03 & 5.85 & 1.54 \\
\hline & M5 & 30 & 0 & 9.4 & 12.4 & 7.02 & 0.00 & 13.45 & 9.75 & 9.75 & 0.00 & 7.02 & 0.00 \\
\hline
\end{tabular}

\subsubsection{Determination of the amount of consumed alkali}

As described previously, the first step of the model was the calculation of the amount of consumed alkali which causes ASR expansion. The calculations presented in this part are summarized up in Table 4.

The proportions of reactive aggregate in sand composition are given in columns 1 and 2. As explained earlier and described in the flow chart (Fig. 5), the first calculation was the amount of required alkali $\left(A_{\mathrm{R} i}\right)$ needed to obtain the maximal ASR expansion. $A_{\mathrm{R} i}$ depended on the reactive silica content $\left(s_{i}\right)$ of each reactive particle size fraction; 9.4 and $12.4 \%$ were determined for F1 and F3 respectively (columns 3 and 4). Using the amount of required alkali per $\mathrm{kg}$ of reactive silica ( $r=15.4 \%$ ) obtained from Poyet's experiment (Section 4.2.1), $A_{\mathrm{R} i}\left(\mathrm{~kg} / \mathrm{m}^{3}\right)$ was calculated from Eq. (4) for the two reactive particle size fractions (columns 5 and 6).

ASR expansion depended on the amount of available alkali compared to the amount of required alkali. The total amount of available alkali $\left(A_{\mathrm{T}}\right)$ was 6.18 and $13.45 \mathrm{~kg} \mathrm{Na}_{2} \mathrm{O}_{\text {eq }}$ per $\mathrm{m}^{3}$ of concrete (column 7). Then, after having taken account of the threshold of alkali $\left(A_{0}=3.7 \mathrm{~kg}\right.$ of $\left.\mathrm{Na}_{2} \mathrm{O}_{\mathrm{eq}}\right)$, the amounts $\left(A_{\mathrm{A}}\right)$ of

Table 5

Comparison between measured and calculated values of expansion

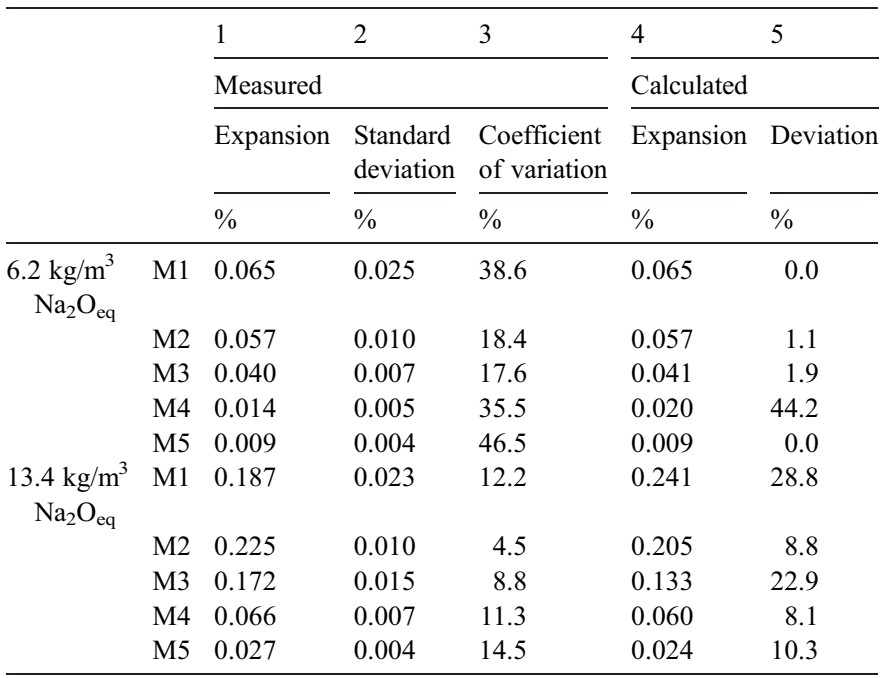

alkali available to react with the reactive silica were $2.48 \mathrm{~kg} / \mathrm{m}^{3}$ and $9.75 \mathrm{~kg} / \mathrm{m}^{3}$ (column 8). This amount $A_{\mathrm{A}}$ reacted with the reactive particles proportionally to the reactive silica content as described in Eq. (4) (columns 9 and 10). Then, the amount of alkali really consumed in the reaction $\left(A_{\mathrm{C} i}\right)$ was determined by Eq. (5) (columns 11 and 12).

\subsubsection{Determination of the ASR expansions}

The second step consisted of calculating the ASR expansion of the mortars. All the measurements and calculations discussed in this part are summed up in Table 5 .

The first three columns show the means, standard deviations and coefficients of variation of ASR expansion measured on the ten mortars. The values of the coefficients of variation of these measurements (between 5 and 50\%) point out that ASR expansion always shows large scatter due to heterogeneous expansion as already described in $[25,26]$.

In order to calculate the ASR expansion of all mortars, the maximum expansion related to each size fraction must be determined. Then, the ASR expansion of mortar Fi is the sum of the ASR expansion of each size fraction contained in the mortar, proportionally to the reactive particles content and to the $A_{\mathrm{C} i} / A_{\mathrm{R} i}$ ratio (Eq. (6)).

The ASR expansion of mortars containing particle size fractions F1 and F3 were assessed using the measurements performed on M5 and M1 mortars with the low alkali contents $\left(\varepsilon_{\mathrm{M} 5}\right.$ and $\varepsilon_{\mathrm{M} 1}$ for $6.2 \mathrm{~kg} / \mathrm{m}^{3}$ ). For this content, Table 4 shows that there were not enough alkali to obtain the maximal expansion (the amount of available alkali was lower than the amount of required alkali). With the assumption of proportionality between ASR expansions and the amount of available alkali, it can be written that:

$\varepsilon_{i}=\frac{\varepsilon_{\mathrm{M} i}}{s_{i} \times p_{i} \times \mathrm{SC}} \times \frac{A_{\mathrm{R} i}}{A_{\mathrm{A} i}}$

Using $0.009 \%$ and $0.065 \%$ for the expansion values measured on mortars M5 and M1 respectively (column 1), calculations gave $5.3410^{-4}$ and $4.0210^{-3} \% \mathrm{~kg}^{-1}$ for the ratios $\varepsilon_{1}$ and $\varepsilon_{3}$ of the two fractions F1 and F3. The ASR expansions could then be calculated for all the mortars (column 4). 


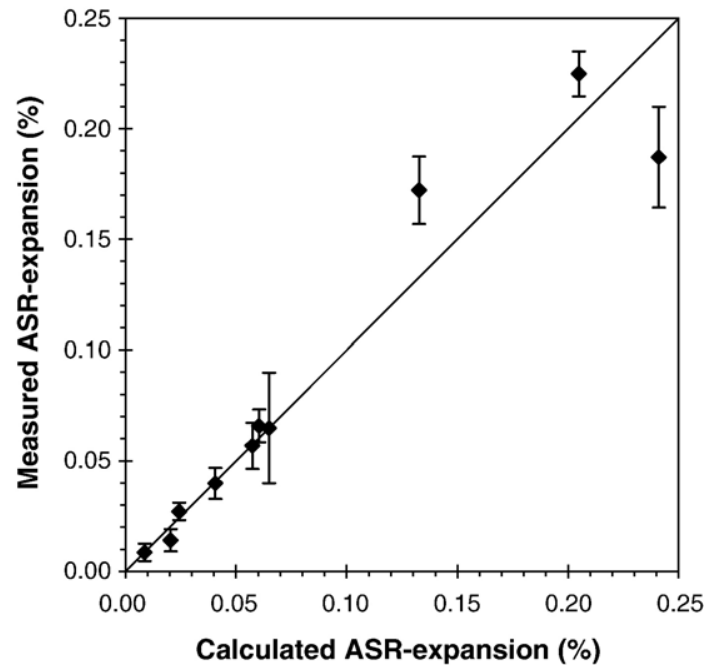

Fig. 7. Comparison between measured and calculated expansions.

Fig. 7 shows an acceptable correlation between measured and calculated ASR expansions, since the deviations between the two values (column 5) are of the same order of magnitude as the standard deviations of the measured expansion values (column 3). In spite of the simplicity of the assumptions, it seems possible to predict ASR expansion of eight mortars by using only the expansion measured on two mortars as input data. The calculated expansion deviated from the measured expansion by $0-44 \%$ (mean value of $15 \%$ ), depending on the particle size combination of the mortar. These values are in the same order of magnitude than the dispersion of the measurements $(5-50 \%$ with a mean value of $20 \%)$. Consequently it is assumed that this approach gives acceptable results.

\section{Conclusion}

The experimental work shows that ASR-expansion was seven times larger for coarse particles $(1.25-3.15 \mathrm{~mm})$ than for smaller ones $(80-160 \mu \mathrm{m})$. The quantification of alkali soluble silica, performed on the different particle size fractions, showed that all the reactive particles contained almost the same amount of reactive silica. Therefore, this factor did not cause the differences in the swelling behavior of the mortars containing the different size fractions. In mortars for which the two size fractions were used, ASR-expansion increased proportionally to the amount of coarse reactive particles with a linear trend, for two different alkali contents.

The analysis has put forward an empirical model based on the summation of the ASR expansion values of the different size fractions and on the amounts of available and required alkali which react with the reactive silica, assessed from Poyet's experimental study [13]. Using the expansion measured on two mixtures, it was possible to calculate the expansion of eight other mixtures containing various combinations of two particles size fractions of a reactive siliceous limestone. The measured and calculated values of ASR expansion differed by $0-44 \%$ depending on the particle size combination of the reactive aggregate. The model need to be tested on other mixtures to quantify, for example, the experimentally observed decrease of ASR expansion when reactive fine particles are added to concrete $[8,12]$. Besides, this model can be considered as a first step to predict the potential ASR expansion from the initial amount of alkali and reactive silica. Further work will seek to improve the empirical correlations. Additional particle sizes should be included in the analysis and the replacement of some linear functions (such as expansion versus alkali content) by non-linear relations should be considered, in order to take account of the filling of the connected porosity and the effect of cracking on ASR expansion.

\section{Notation}

$A_{\mathrm{T}} \quad$ total available alkali content in a mortar

$A_{0} \quad$ threshold of alkali per $\mathrm{m}^{3}$ of concrete

$A_{\mathrm{A}} \quad$ amount of available alkali in a mortar after the threshold $A_{0}$ is reached

$A_{\mathrm{A} i} \quad$ amount of available alkali for fraction $F_{i}$

$A_{\mathrm{R} i} \quad$ amount of required alkali for fraction $F_{i}$

$A_{\mathrm{C} i} \quad$ amount of alkali consumed for fraction $F_{i}$

$p_{i} \quad$ proportion of particles of fraction $F_{i}$ in the sand composition

$r \quad$ amount of required alkali per $\mathrm{kg}$ of reactive silica

$s_{i} \quad$ proportion of reactive silica in particles $F_{i}$

$\mathrm{SC} \quad$ sand content in a mortar

$\varepsilon_{I} \quad$ ratio of maximal ASR expansion measured on a mortar per kg of reactive silica of fraction $F_{i}$.

\section{Acknowledgments}

The authors are grateful to EDF for supporting this work.

\section{References}

[1] S. Diamond, N. Thaulow, A study of expansion due to alkali-silica reaction as conditioned by the grain size of the reactive aggregate, Cement and Concrete Research 4 (4) (1974) 591-607.

[2] M. Kawamura, K. Takemoto, S. Hasaba, Application of quantitative EDXA analyses and microhardness measurements to the study of alkali-silica reaction mechanisms, in: G.M. Idorn, S. Rostam (Eds.), 6th International Conference of Alkali in Concrete, Danish Concrete Association, Kobenhavn, Copenhagen, Denmark, 1983, pp. 167-174.

[3] X. Zhang, G.W. Groves, The alkali-silica reaction in OPC-silica glass mortar with particular reference to pessimum effects, Advances in Cement Research 3 (9) (1990) 9-13.

[4] H.E. Vivian, Studies in cement-aggregate reaction. XIX: the effect on mortar expansion of the particle size of the reactive component in the aggregate, Australian Journal of Applied Science 2 (1951) 488-494.

[5] L. Hasni, Y. Gallias, M. Salomon, Appréciation des risques d'alcaliréaction dans les bétons de sable, Rapport de recherche $n^{\circ} 41020$, Centre Expérimental de Recherches et d'Etudes du Bâtiment et des Travaux Publics (CEBTP), St-Rémy-lès-Chevreuses, 1993, 53pp.

[6] Y. Shao, T. Lefort, S. Moras, D. Rodriguez, Studies on concrete containing ground waste glass, Cement and Concrete Research 30 (1) (2000) 91-100.

[7] P.P. Hudec, R. Cyrus Ghamari, Ground waste glass as an alkali-silica reactivity inhibitor, in: M.A. Bérubé, B. Fournier, B. Durand (Eds.), 11th International Conference on Alkali-Aggregate Reaction in Concrete, Centre de Recherche Interuniversitaire sur le Béton (CRIB), Québec, Canada, 2000, pp. 663-672. 
[8] M. Moisson, M. Cyr, E. Ringot, A. Carles-Gibergues, Efficiency of reactive aggregate powder in controlling the expansion of concrete affected by alkali-silica reaction (ASR), in: M. Tang, M. Deng (Eds.), 12th International Conference on Alkali-Aggregate Reaction in Concrete, Academic Publisher, Beijing, China, 2004, pp. 617-624.

[9] Z. Xie, W. Xiang, Y. Xi, ASR potentials of glass aggregates in water-glass activated fly ash and portland cement mortars, Journal of Materials in Civil Engineering 15 (1) (2003) 67-74.

[10] K. Ramyar, A. Topal, O. Andic, Effects of aggregate size and angularity on alkali-silica reaction, Cement and Concrete Research 35 (11) (2005) 2165-2169.

[11] N.Q. Feng, T.Y. Hao, X.X. Feng, Study of the alkali reactivity of aggregates used in Beijing, Magazine of Concrete Research 54 (4) (2002) 233-237.

[12] J.S. Guédon-Dubied, G. Cadoret, V. Durieux, F. Martineau, P. Fasseu, V. van Overbecke, Study on Tournai limestone in Antoing Cimescaut Quarry. Petrological, chemical and alkali reactivity approach, in: M.A. Bérubé, B. Fournier, B. Durand (Eds.), 11th International Conference on AlkaliAggregate Reaction in Concrete, Centre de Recherche Interuniversitaire sur le Béton (CRIB), Québec, Canada, 2000, pp. 335-344.

[13] S. Poyet, Etude de la dégradation des ouvrages en béton atteints par la réaction alcali-silice: Approche expérimentale et modélisation numérique multi-échelles des dégradations dans un environnement hydro-chemomécanique variable, Ph.D. Thesis (in French), Université de Marne-LaVallée, 2003.

[14] L. Dramais, Comportement chimique de la silice vitreuse et de l'opale dans les milieux basiques - Application à l'étude de la réaction alcali-granulat dans les bétons hydrauliques, Ph.D. Thesis (in French), Université Claude Bernard - Lyon I, 1991.

[15] Z. Wen, Formation et caractérisation de sols alcalins et de silice - Conditions de leur transformation en gel au contact de sels et d'hydroxydes, notamment de ceux qui sont présents dans le béton, Ph.D. Thesis (in French), Université de Bourgogne, 1989.

[16] V. Adrover, Contribution à l'étude de l'attaque de minéraux et de roches par des solutions hyperalcalines, Ph.D. Thesis (in French), E.N.S.M. Paris, 1995.

[17] T.N. Jones, A.B. Poole, Alkali-silica reaction in several U.K. concretes: the effect of temperature and humidity on expansion, and the significance of ettringite development, in: P.E. Grattan-Bellew (Ed.), 7th International Conference on Alkali-Aggregate Reaction in Concrete, Noyes Publications, Park Ridge, USA, 1986, pp. 446-450.

[18] P.K. Mukherjee, J.A. Bickley, Performance of glass as concrete aggregates, in: P.E. Grattan-Bellew (Ed.), 7th International Conference on AlkaliAggregate Reaction in Concrete, Noyes Publications, Park Ridge, USA, 1986, pp. 36-42.

[19] A. Carles-Gibergues, M. Cyr, Interpretation of expansion curves of concrete subjected to accelerated alkali-aggregate reaction (AAR) tests, Cement and Concrete Research 32 (5) (2002) 691-700.

[20] R.E. Oberholster, Alkali reactivity of siliceous rock aggregates: diagnosis of the reaction, testing of cement and aggregate and prescription of preventive measures, in: G.M. Idorn, S. Rostam (Eds.), 6th International Conference on Alkali-Aggregate Reaction in Concrete, Danish Concrete Association, Kobenhavn, Copenhagen, Denmark, 1983, pp. 419-433.

[21] C.A. Rogers, R.D. Hooton, Reduction in mortar and concrete expansion with reactive aggregates due to alkali leaching, Cement, Concrete and Aggregates 13 (1) (1991) 42-49.

[22] D.W. Hobbs, Deleterious alkali-silica reactivity in the laboratory and under field conditions, Magazine of Concrete Research 45 (163) (1993) $103-112$.

[23] M.D.A. Thomas, B.Q. Blackwell, P.J. Nixon, Estimating the alkali contribution from fly ash to expansion due to alkali-aggregate reaction in concrete, Magazine of Concrete Research 48 (177) (1996) 251-264.

[24] M.H. Shehata, M.D.A. Thomas, The effect of fly ash composition on the expansion of concrete due to alkali-silica reaction, Cement and Concrete Research 30 (7) (2000) 1063-1072.

[25] C. Larive, M. Joly, O. Coussy, Heterogeneity and anisotropy in ASRaffected concrete - Consequences for structural assessment, in: M.A. Bérubé, B. Fournier, B. Durand (Eds.), 11th International Conference on Alkali-Aggregate Reaction in Concrete, Centre de Recherche Interuniversitaire sur le Béton (CRIB), Québec, Canada, 2000, pp. 969-978.

[26] S. Multon, J.-F. Seignol, F. Toutlemonde, Structural behavior of concrete beams affected by ASR, ACI Materials Journal 102 (2) (2005) 67-76. 